\title{
The rare occurrence of cutaneous and mucosal lichen planus in HIV infection
}

\author{
Preet Mukesh Shah, ${ }^{1}$ Vijay Waman Dhakre ${ }^{2}$
}

'Department of Critical Care, Jaslok Hospital and Research Centre, Mumbai, India ${ }^{2}$ Department of Surgical Gastroenterology, Jaslok Hospital and Research Centre, Mumbai, India

\section{Correspondence to} Dr Preet Mukesh Shah, drpreetshah@gmail.com

Presented as a poster at APICON 2017

Accepted 3 November 2017

\section{DESCRIPTION}

A 36-year-old man, a rickshaw driver by profession, who was diagnosed with HIV infection 3 years back, was on regular antiretroviral therapy consisting of zidovudine, lamivudine and nevirapine. He presented with complaints of a pruritic rash on both his legs since 7 months, which started as a single lesion and gradually spread to the current state over the next 6 weeks. Barring his antiretroviral therapy, he did not have any other drug history. He did not consume alcohol, did not chew tobacco and did not smoke. His CD4-positive cell count at the time of presentation was $336 / \mathrm{mm}^{3}$, serology for hepatitis $\mathrm{C}$ virus and hepatitis $\mathrm{B}$ virus was negative and other laboratory parameters such as complete blood count, liver and renal function tests were normal.

On examination, he had polygonal, planar, purple papules over the anterior aspect of legs (figure 1), and also white lacy lines (with a reticular pattern) in the left buccal mucosa (figure 2), which were suggestive of Wickham striae.

Keeping in mind the oral and skin lesions, we considered the differentials as either lichen planus (LP) or lichenoid drug eruption due to zidovudine.

Our patient had Wickham striae, which is characteristic of LP, and has a good correlation to the histological features of the disease. He did not give consent for a skin biopsy.

This is a rare case, since there have only been few case reports of LP being seen in patients with HIV, and no specific prevalence has been mentioned. ${ }^{1}$

LP is a cell-mediated immune response-the aetiology of which is unclear. It may be found in association with ulcerative colitis, vitiligo, dermatomyositis, myasthenia gravis, hepatitis $\mathrm{C}$ and primary biliary cirrhosis. Drugs like non-steroidal

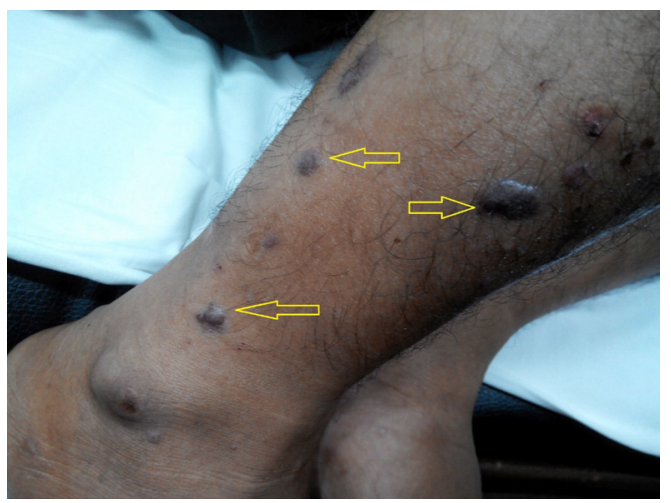

Figure 1 Cutaneous lesions of lichen planus (yellow arrows) (polygonal, planar, purple papules).

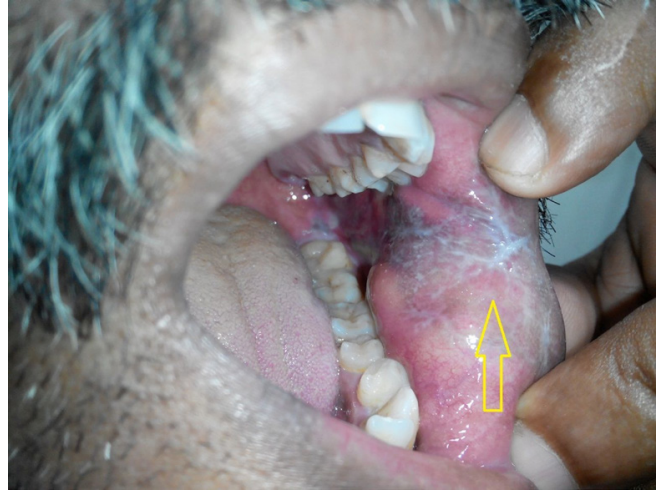

Figure 2 Mucosal lesions of lichen planus (yellow arrow) (white lacy lines with a reticular pattern).

anti-inflammatory drugs, beta-blockers, methyldopa, penicillamine and quinidine have also been implicated. ${ }^{2}$ LP usually affects middleaged adults. The exact prevalence of LP is

\section{Patient's perspective}

I delayed going to the doctor thinking that it may just be a simple rash. With my condition, any new skin problem must be told to the treating doctor as soon as possible.

\section{Learning points}

- Cutaneous lesions in HIV-infected individuals should be evaluated in detail and not be ignored.

- The physician treating HIV-infected individuals should take detailed drug history from them and should also be aware of pathophysiology of lichen planus (LP).

- Patients infected with HIV, hepatitis B virus or hepatitis $C$ virus should be educated regarding various dermatological manifestations of their condition and should report these to their treating physician during follow-up.

- Examination of the mucosa is important in patients with cutaneous features suggestive of $L P$, since the presence of Wickham striae is pathognomonic of the disease.

- Histopathological analysis reveals detailed features of LP, and direct immunofluorescence helps in differentiating between LP and other lesions that are difficult to differentiate clinically and histopathologically. 
unknown. Nevertheless, the estimated prevalence of LP is in the range of $0.22 \%-5 \%$ worldwide. ${ }^{3}$

The presence of Wickham striae on the mucosa is pathognomonic of LP; however, its absence does not rule out the disease. LP is diagnosed clinically with the features confirmed and differentiated from other lesions using direct immunofluorescence.

The pathogenesis of development of LP in an individual infected with HIV is probably due to the suppression of the CD4-positive cells in these patients. It could also be due to differences in antigenic presentation and altered immune response to antigenic stimuli in these immunocompromised patients.

Contributors PMS wrote up the case details and acquired the clinical photographs. VMD assisted in the discussion and looking up the necessary references.
Competing interests None declared.

\section{Patient consent Obtained.}

Provenance and peer review Not commissioned; externally peer reviewed.

(C) BMJ Publishing Group Ltd (unless otherwise stated in the text of the article) 2017. All rights reserved. No commercial use is permitted unless otherwise expressly granted.

\section{REFERENCES}

1 Emadi SN, Akhavan-Mogaddam J, Yousefi M, et al. Extensive hypertrophic lichen planus in an HIV positive patient. Dermatol Online J 2010;16:8.

2 Thompson DF, Skaehill PA. Drug-induced lichen planus. Pharmacotherapy 1994;14:561-71.

3 Gorouhi F, Davari P, Fazel N. Cutaneous and mucosal lichen planus: a comprehensive review of clinical subtypes, risk factors, diagnosis, and prognosis. Sci World J 2014:2014:1-22.

Copyright 2017 BMJ Publishing Group. All rights reserved. For permission to reuse any of this content visit http://group.bmj.com/group/rights-licensing/permissions.

BMJ Case Report Fellows may re-use this article for personal use and teaching without any further permission.

Become a Fellow of BMJ Case Reports today and you can:

- Submit as many cases as you like

- Enjoy fast sympathetic peer review and rapid publication of accepted articles

- Access all the published articles

Re-use any of the published material for personal use and teaching without further permission

For information on Institutional Fellowships contact consortiasales@bmjgroup.com

Visit casereports.bmj.com for more articles like this and to become a Fellow 